\title{
ビワ果実の貯蔵中のプロビタミン $\mathrm{A}$ および ビタミン C 含量の変化
}

\author{
浜渦康範* ・ 茶珍和雄* ・黒岡 浩*
}

\author{
Changes in Provitamin A and Vitamin C Contents of \\ Loquat Fruit during Storage
}

\author{
Yasunori Hamauzu*, Kazuo Chachin* and Hiroshi KurookA* \\ College of Agriculture, University of Osaka Prefecture, \\ Mozu-umemachi, Sakai, Osaka 591
}

\begin{abstract}
Changes in provitamin A and vitamin C contents during storage of 'Mogi' loquat fruit were studied. For determination of provitamin $\mathrm{A}$, the fruits were packaged in perforated polyethylene bags and stored at $18^{\circ} \mathrm{C}, 5^{\circ} \mathrm{C}$ and $1^{\circ} \mathrm{C}$. In carotenoids of 'Mogi' fruits, $\beta$-carotene and cryptoxanthin were detected as provitamin $\mathrm{A}$ active compounds. $\beta$-Carotene content did not decrease during the storage at all of three storage temperatures, and cryptoxanthin content was almost constant. The vitamin A activity of loquat fruit calculated from provitamin A content showed high nutritive value of $600 \sim 850 \mathrm{IU} / 100 \mathrm{~g}$ f.w. throughout the storage period.

For determination of ascorbic acid, loquat fruits were packaged in sealed or perforated polyethylene bags $\left(30 \mu \mathrm{m}\right.$ thickness) and stored at $18^{\circ} \mathrm{C}$ and $1{ }^{\circ} \mathrm{C}$. The total ascorbic acid in the fruit stored at $18^{\circ} \mathrm{C}$ tended to increase, while it decreased progressively in both of two packaging conditions at $1{ }^{\circ} \mathrm{C}$. Ratio of reduced ascorbic acid to total ascorbic acid was low showing about $30 \%$ even at harvest, and it furthermore lowered during storage.

(Received Jul. 30, 1990)
\end{abstract}

\section{緒言}

生体内でビタミン $\mathrm{A}$ 作用物質に転換される物質はプロ ビタミン $\mathrm{A}$ と呼ばれ， $\beta$-イオニリデン末端基を持つカロ チノイドはその代表的なもので，青果物に多く含まれて いる。青果物はビタミン類, 特にビタミンCやプロビタ ミンAの給源として重要であり, ビタミンCについては

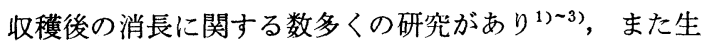
理・化学的面からも調查が行われてきた ${ }^{4), 5)}$ が, プロビ タミンAについては測定に時間・手間がかかることもあ り, 研究は多くない。ビワ果実の発育中のカロチノイド 系色素の変化については, 近ら ${ }^{6)}$ の研究により, 田中ビ ワの果肉において $\beta$-カロチン, クリプトキサンチンの成 熟過程での増加が報告されている。
ビワ果実のビタミン $\mathrm{A}$ 効力は四訂食品成分表によると $400 \mathrm{IU} / 100 \mathrm{~g}$ f.w. で果実類の中では多い方であり, 一方 ビタミンCは少なく $5 \mathrm{mg} / 100 \mathrm{~g}$ f.w. とされている。しか し，いずれの成分についても貯蔵中の消長に関する報告 はみられない。

本実験ではカロチノイドを多く含む果実であるビワを 試料に用い, 貯蔵中のプロビタミンAの変化を検討する とともに，アスコルビン酸（ビタミンC）について酸化 型と還元型の変化を調べ, 貯蔵中のビタミンC含量の動 向を調べた。

\section{実験方法}

\section{1. 実験 材 料}

大阪府立大学附属農場で収穫されたビワ果実“茂木” 
を実験材料に用いた。プロビタミンAの分析には1988年 に出荷熟度（Fig.5 における Ripening stage 7) で収 穫されたものを用い，開孔率約 $0.5 \%$ の有孔低密度ポリ エチレン袋に 6 個ずつ包装し，18 $\mathrm{C}, 5{ }^{\circ} \mathrm{C}, 1^{\circ} \mathrm{C}$ の各温度 で貯蔵した。

アスコルビン酸の分析は1989年に前年度とほぼ同じ熟 度で収穫された果実について，ポリエチレン袋（厚さ30 $\mu \mathrm{m})$ の有孔区之密封区を設け, $18^{\circ} \mathrm{C}, 1^{\circ} \mathrm{C}$ の温度下に貯 蔵して調査した。そのほか, 種々の熟度段階で収穫した 果穾につき, 収穫直後の值を測定した。なお，化学成分 の分析は果皮及び種子を除いた果肉について行った。

\section{2. カロチノイド色素の抽出と定量およびビタミンA} 効力の評価

(1) カロチノイド色素の抽出試料からのカ口チ， イド色素の抽出は梅田らうの方法に準じて下記のように 行った。なお，本実験では近ら ${ }^{6)}$ の報告を参考にし，抗 酸化剮としてブチルヒドロキシトルエン $(\mathrm{BHT})$ を用い た。ビワ果寒の果肉部 $20 \mathrm{~g}$ を炭酸マグネシウム $(0.5 \mathrm{~g})$, BHT (0.25g) とともに $40 \%$ タノール約 $20 \mathrm{~m} l$ 中でホ モジナイズした。あらかじめセライト 545 を敷いたグラ スフィルター（G 3) 上に40\%メタノールとともに洗い 移し, 吸引ろ過しつつ $40 \%$ メタノールでろ液に着色がな くなるまで洗浄した。残渣を着色がなくなるまでアセ卜 ンで抽出し, 抽出液はロータリーエバポレーターで濃縮 （40〜 45ㄷ）した。濃縮液にエチルエーテルを加え，分 液漏斗内でカロチノイドをエーテル層に移した後, 水で よく洗浄した。

得られたカロチノイドのエーテル溶液に $20 \%(\mathrm{w} / \mathrm{v})$ 水 酸化カリウムーメタノールを加え, 窒素ガスを吹き込ん だ後, 冷蔵庫で一晚けん化した。けん化溶液は分液漏斗 に移し，食塩水を加えてェマルジョン化を防ぎつつ水で よく洗浄した。続いて無水硫酸ナトリウムを加え，1時 間以上放置して脱水した後，エーテルで一定容とした。 このカロチノイドのエーテル溶液について波長 $451 \mathrm{~nm}$ の吸光度を測定し, $\beta$-カ口チン相当量 $\left(\mathrm{E}_{1 \mathrm{~cm}}^{1 \%}=2500\right)$ として全カロチ/イド含量を測定した。

(2) TLC による分離 カロチノイドの分離・定量 は $\mathrm{Gross}^{8}$ おおよび梅田ら ${ }^{7}$ の方法に準じて行った。TLC 吸着剤は, シリカゲル (WAKOGEL B-5) と酸化アル ミニウムを1：1で混合したもので，プレートに厚さ $0.25 \mathrm{~mm}$ に敷き, $110^{\circ} \mathrm{C}$ で一晚活性化した。一定容にし たカロチノイドのエーテル溶液の一定量を濃縮し, この 濃縮液の一定量を毛細管でプレート上に線状にスポット した。展開剤は石油エーテルアセトン $(80: 20)$ で，暗
黒下で30 40分間展開させた。展開して得られた各バン ドは直ちにスパチュラで削り取り、エーテルで再び溶出 させた。エーテルのみでは溶出しないカロチノイドは少 量のメタノールを加えて溶出させた。各カロチノイドの エーテル溶液はエーテルで一定容として $451 \mathrm{~nm}$ の波長で 吸光度を測定し， $\beta$-カロチン換算で含量を計算するとと もに全カロチノイドに対する割合を算出した。

(3) 各カロチノイドグループの同定 カロチノイド の同定は吸着層に対する吸着能，標準カロチノイドの吸 着位置との比較, 自記分光光度計による吸収曲線, エポ キシドの検出などによって行った。エポキシドの検出は 梅田ら ${ }^{2)}$ の方法に準じ，クエン酸テストにより 5，6-エ ポキシドの数を, 塩酸テストにより総エポキシド数を推 定した。

(4) ビタミンA効力の評価 プロビタミンA含量か らビタミン A 効力への換算は一般に用いられているよう にレチノール $0.3 \mu \mathrm{g}$ を 1 国際単位 (IU) とし， $\beta$-カ口チ ンの腸管吸収率を $1 / 3$ ，レチノールへの変換率を $1 / 2$ と しで）計算した。本実験ではß-カロチン以外のプロビタ ミンAについても効力への換算を行い，クリプトキサン

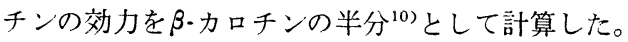

\section{3. アスコルビン酸の測定}

アスコルビン酸含量の測定は，5個体の果実より放射 状に切り出した果肉 $5 \mathrm{~g}$ のメタリン酸抽出液（終末濃 度

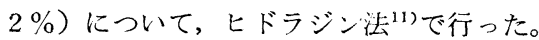

\section{結果および考察}

\section{1. ビワ果実の果肉中のカロチノイド}

図1にビワ果実のカロチノイドの TLC による分離状 態を示した。標準カロチノイドとして市販 $\beta$-カロチン，

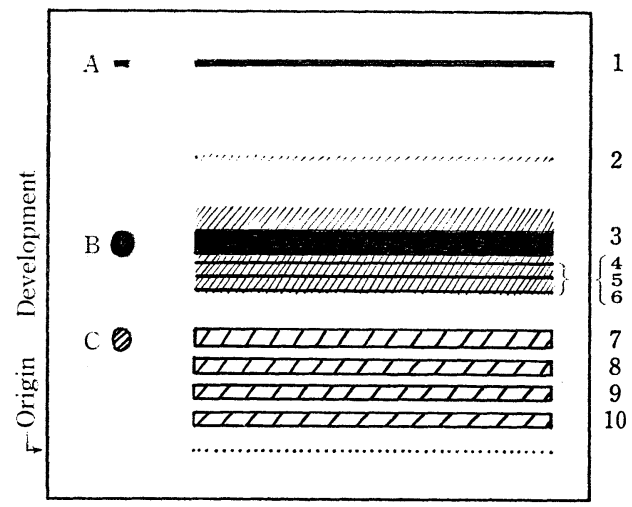

Fig.1 TLC of carotenoids in 'Mogi' loquat fruit A: $\beta$-Carotene, B : Cryptoxanthin, $\mathrm{C}$ : Lutein 
Table 1 Characterization of carotenoid fractions isolated from 'Mogi' loquat fruit by TLC

\begin{tabular}{|c|c|c|c|c|c|c|c|c|c|c|c|c|}
\hline \multirow{2}{*}{$\begin{array}{l}\text { Fraction } \\
\text { No. }\end{array}$} & \multirow{2}{*}{$\begin{array}{c}\begin{array}{c}\text { Citric acid } \\
\text { test }\end{array} \\
\text { Shift }(\mathrm{nm})\end{array}$} & \multirow{2}{*}{$\frac{\begin{array}{c}\mathrm{HCl} \\
\text { test }\end{array}}{\text { Blue color }}$} & \multirow{2}{*}{$\begin{array}{l}\text { Number } \\
\text { of } \\
\text { epoxide }\end{array}$} & \multirow{2}{*}{$\begin{array}{c}\text { Number } \\
\text { of } \\
\mathrm{OH}\end{array}$} & \multirow{2}{*}{ Group } & \multicolumn{6}{|c|}{ Spectral absorption maxima } & \multirow{2}{*}{$\begin{array}{l}\text { Authentic } \\
\text { compounds }\end{array}$} \\
\hline & & & & & & \multicolumn{3}{|c|}{$\stackrel{\text { Hexane }}{\text { 【reference }}{ }^{12)} \searrow$} & \multicolumn{3}{|c|}{$\begin{array}{l}\text { Pet. ether } \\
\text { [reference }{ }^{12)} \text { 】 }\end{array}$} & \\
\hline \multirow[t]{2}{*}{1} & 0 & $-*$ & 0 & 0 & $\mathrm{H}$ & $(427)$ & 450 & 477 & $(425)$ & 448 & 476 & \\
\hline & & & & & & 【(425) & 450 & 477】 & $【(425)$ & 448 & 475】 & $\beta$-Carotene \\
\hline 2 & & & & & & & & & 402 & 474 & 498 & \\
\hline \multirow[t]{2}{*}{3} & 0 & - & 0 & 1 & M & $(425)$ & 448 & 477 & (426) & 448 & 476 & \\
\hline & & & & & & 【(425) & 446 & 475】 & $【 425$ & 449 & 476】 & Cryptoxanthin \\
\hline \multirow[t]{2}{*}{4} & 0 & ++ & 1 & 1 & MM & 404 & 428 & 454 & 402 & 426 & 450 & \\
\hline & & & & & & 【403 & 425 & $452 \searrow^{133}$ & 【403 & 424 & 450】 & Cryptoflavin \\
\hline 5 & 0 & +++ & 2 & 1 & MD & 402 & 427 & 452 & 401 & 426 & 448 & \\
\hline 6 & 48 & ++ & 2 & 1 & MD & 400 & 426 & 447 & 399 & 423 & 446 & \\
\hline 7 & 0 & + & 1 & 2 & $\mathrm{DM}$ & 402 & 427 & $(451)$ & 401 & 426 & 448 & \\
\hline 8 & 19 & ++ & 1 & 2 & DM & 400 & 424 & 445 & 399 & 422 & 445 & \\
\hline \multirow[t]{2}{*}{9} & 20 & $++t$ & 2 & 2 & D D & 399 & 421 & 445 & & & & \\
\hline & & & & & & 【399 & 422 & 448】 & & & & Luteoxanthin \\
\hline 10 & 20 & ++ & 1 & $\geqq 3$ & $\mathrm{PM}$ & 399 & 422 & 447 & & & & \\
\hline
\end{tabular}

$*$ colorless $(-) \leftarrow$ blue $\rightarrow(++)$ deep blue

$\mathrm{H}=$ hydrocarbon group, $\mathrm{M}=$ monol group, $\mathrm{D}=$ diol group, $\mathrm{DM}=$ diol monoepoxide group

$\mathrm{DD}=$ diol diepoxide group, $\mathrm{PM}=$ polyol monoepoxide group

カキ果実からのクリプトキサンチン，卵黄からのルテ インを用いた。これらの位置より 1 番のバンドは $\beta$-カ口 チンと同グループのハイドロカーボン類， 3 番のバンド はクリプトキサンチンと同グループ，即ち水酸基を 1 つ 持ったモノール類であり， 7 番のバンドは水酸基を $2 つ$ 持ったルテインの位置と等しいためジオールグループで あると推定した。分離された10種類のカロチノイドにつ いて，それぞれ主体となるカロチノイドの同定を試みた 結果，4つのグループについて代表的なカロチノイドを 同定できた（表 1 ）。

同定はへキサン内，石油エーテル内での吸収極大の測 定值を文献值 ${ }^{12), 13)}$ と比較し，他の条件を満たすことを 確認した上で決定した。1番のフラクションは $\boldsymbol{\beta}$-カロチ ンを主体とするカロチノイドであり， 3 番のフラクショ ンはクリプトキサンチンを主とするグループ，4 番, 9 番のフラクションはそれぞれクリプトフラビン, ルテオ キサンチンが主体であると考えられる。カロチノイドが ビタミンA効力を有するためには, その分子内に少なく とも 1 個の $\beta$-イオノン環（水酸基や酸素の結合のないも の）を持っていなければならないとされている。したが って, 同定されたカロチノイドグループの中でプロビタ ミンAとされるものは $\beta$-カロチン, クリプトキサンチン であり，他のグループは同定できなかったものを含め， ビタミンA効力は有していないと考えられる。

なお， $\beta$-カロチンを含むハイドロカーボン類とクリプ トキサンチンを含むモノール類について, Gross ${ }^{5)}$ の方
法で再分離を行ったところ，モノール類では分離が認め られす，ハイドロカーボン類に掠いては 1 本の細いバン ドが分離されたが, 量的にわずかであったため, 以後再 分離は行わなかった。

\section{2. ビワ果実の貯蔵中のカロチノイド含量の変化}

表 2 にビワ果実の貯蔵に伴うカロチノイド含量の変化 を示した。各温度区とも貯蔵中 $\beta$-カロチン含量はバラッ キがあるが最終的に收穫日の含量と比較して減少するこ

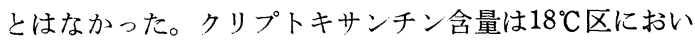
て $\beta$-カロチンと同様の変化で $\beta$-カロチン含量を上まわっ ていたが $5{ }^{\circ} \mathrm{C}$ 区では貯蔵87日後に $\beta$-カロチン含量を下ま わり，1ㄷ区ではほぼ等しくなっていた。

Table 2 Changes in carotenoids content of 'Mogi' loquat fruit during storage

\begin{tabular}{rrrccc}
\hline & Days & $\begin{array}{l}\beta \text {-Caro- } \\
\text { tene }\end{array}$ & $\begin{array}{l}\text { Cryptoxan- } \\
\text { thin }\end{array}$ & Others & Total \\
\hline $18^{\circ} \mathrm{C}$ & 0 & $0.71^{*}$ & 0.90 & 0.39 & 2.0 \\
& 3 & 0.58 & 0.71 & 0.71 & 2.0 \\
& 21 & 0.88 & 1.01 & 1.01 & 2.9 \\
\hline $5^{\circ} \mathrm{C}$ & 0 & 0.71 & 0.90 & 0.39 & 2.0 \\
& 21 & 0.92 & 1.06 & 0.52 & 2.5 \\
& 52 & 0.68 & 0.74 & 0.58 & 2.0 \\
& 87 & 0.93 & 0.81 & 0.56 & 2.3 \\
\hline $1^{\circ} \mathrm{C}$ & 0 & 0.71 & 0.90 & 0.39 & 2.0 \\
& 21 & 0.68 & 0.98 & 0.64 & 2.3 \\
& 52 & 0.92 & 1.16 & 0.92 & 3.0 \\
& 87 & 0.92 & 0.93 & 0.75 & 2.6 \\
\hline
\end{tabular}

* mg/100g f.w. 

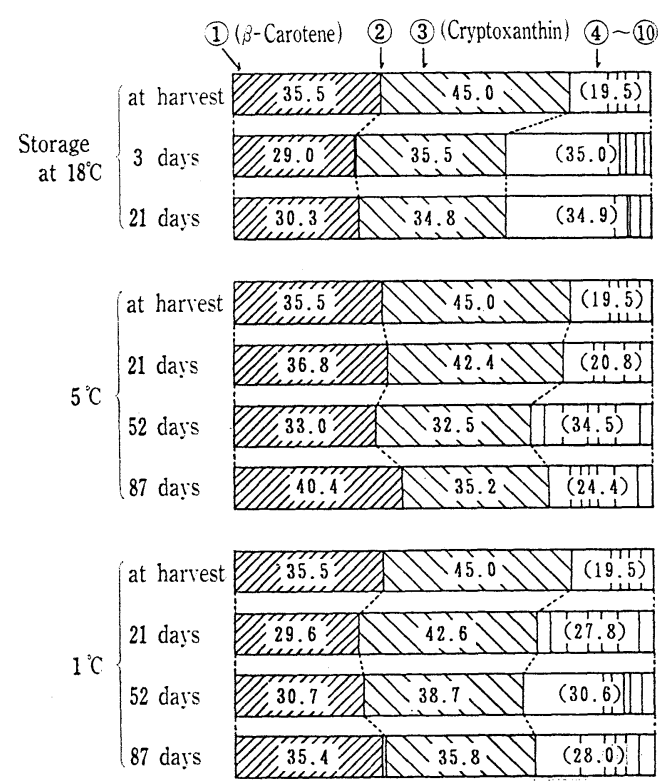

Fig. 2 Changes in proportion of carotenoids in 'Mogi' loquat fruit during storage

また, 全力ロチノイドに対するそれぞれの割合の変化 をみると（図 2), 各温度区においてクリプトキサンチ ンの割合はやや低くなり, ビタミン $\mathrm{A}$ 効力を持たない力 ロチノイドグループの占める割合は高くなった。水酸基 の導入が生合成の最終段階で起こり, エポキシ化はさら に次の段階で起こる ${ }^{14)}$ という報告に基づいて考えると，

4 番以降のカロチノイドは $\beta$-カロチンがクリプトキサン チンを経てさらに変化することによってできたものであ り, これらの含量が増加しているにもかかわらず $\beta$-カ口 チンの含量が減少しないことは貯蔵中のビワ果実におい て $\beta$-カロチンが生合成されている可能性のあることを示 している。

3. ビワ果実の貯蔵中のビタミン A 効力の变化
図 3 は $\beta$-カロチン, クリプトキサンチンの含量をビタ ミンA効力に換算し，ビワ果実貯蔵中のビタミン $\mathrm{A}$ 効力 の変化を示したものである。長期間の貯蔵によってもビ ワ果実におけるビタミンA効力の低下はみられず,この 点において高い栄養価を保持しているといえる。

既述のように, ビワ果実の生体内では $\beta$ ・カロチンから クリプトキサンチンヘ，クリプトキサンチンからさらに エポキシ化されたカロチノイドグループヘと変化してい くと考えられるが，果実が収穫された後も引き続き $\beta$-カ ロチンを合成するため, ビタミンA効力については高い レベルで維持されるものと推察される。

\section{4. ビワ果実の貯蔵中のアスコルビン酸含量の变化}

ビワ果実はアスコルビン酸において酸化型の占める割 合が高いという特徵をもつようで, 収穫直後では酸化型 が約70\%を占め, 貯蔵中にその割合は変動したが，18ㄷ 密封区以外の他の区は最終的にほとんどが酸化型となっ た（図 4 )。

貯蔵中のアスコルビン酸含量の変化は総アスコルビン 酸としてみると, $18^{\circ} \mathrm{C}$ 有孔区は貯蔵 6 日後まで増加し, その後やや減少したが, 密封区では貯蔵21日後まで増加 した。これに対し， $1^{\circ} \mathrm{C}$ 貯蔵では有孔区, 密封区とも徐 々に減少し，63日後のそれぞれの減少率は53\%,82\%で あった。ビワ果実の生育に伴うアスコルビン酸含量の変 化をみると, 途中ある程度バラツキがあるが，完熟する と増加する傾向がみられた（図 5 )。

前述の $18^{\circ} \mathrm{C}$ 貯蔵区でのアスコルビン酸含量の増加は, 樹上における熟成に伴うアスコルビン酸含量の増加現象 と類似しているものと思われる。このような果実におけ る熟成に伴うアスコルビン酸含量の増加はグワバについ て報告されている”。結局, 出荷熟度の果実の貯蔵につ いては, 3 週までの比較では $18^{\circ} \mathrm{C}$ 貯蔵の方が $1^{\circ} \mathrm{C}$ 貯蔵よ りもアスコルビン酸含量が高い結果であった。

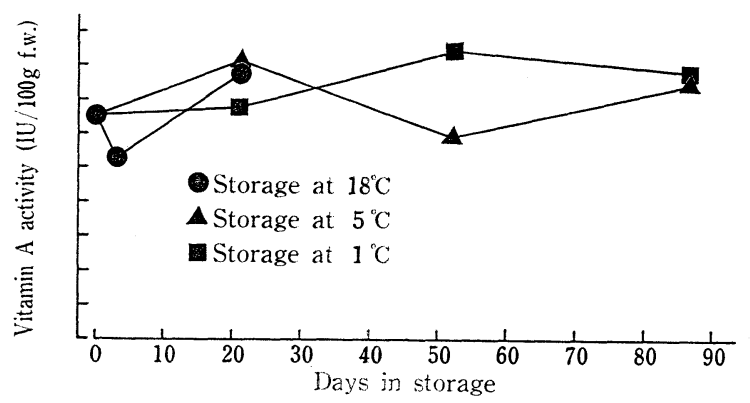

Fig.3 Changes in vitamin A activity of 'Mogi' loquat fruit during storage 


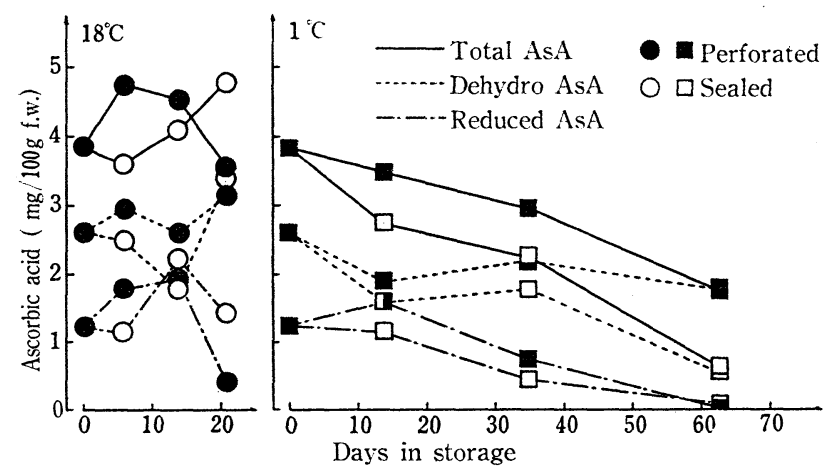

Fig.4 Changes in ascorbic acid content of 'Mogi' loquat fruit during storage

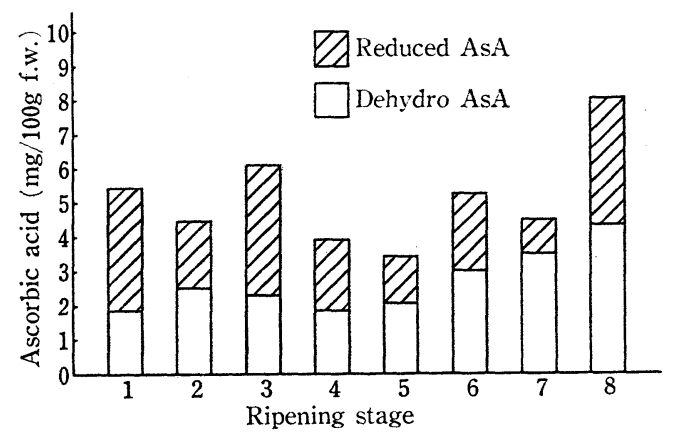

Fig.5 Difference of ascorbic acid content among different ripening stage of 'Mogi' loquat fruit stage 1: Green 2: Yellowish green

3: Greenish yellow $4:$ Light greenish yellow

5: Almost yellow 6: Full yellow

7: Light orange (suitable fot harvest)

8: Dark orange

\section{要 約}

ビワ果実 ‘茂木’の貯蔵中のプロビタミンA タミンC含量の変化を調べた。プロビタミンAの分析 は, 果実を有孔ポリエチレン袋に入れ, $18^{\circ} \mathrm{C}, 5{ }^{\circ} \mathrm{C}, 1$ 드て眝蔵したものについて行った。ビワ果実のカロチノ イドの中で, ビタミン $\mathrm{A}$ とての活性をもっているもの として $\beta$-カロチンとクリプトキサンチンが認められた。 貯蔵中の両者の含量はバラツキがあったが, 最終的に貯 蔵開始日の含量と比較して減少することはなかった。貯 蔵中のビワ果実のプロビタミン $\mathrm{A}$ 含量をビタミン $\mathrm{A}$ 効力 に換算したところ終始 600 850I U/100g f.w. の高い栄 養価を保持していた。

アスコルビン酸（ビタミンC）の測定は，ビワ果実を ポリエチレン袋 $(30 \mu \mathrm{m}$ 厚) 及び有孔ポリエチレン袋に

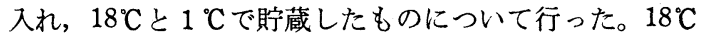
で貯蔵したビワ果実の総アスコルビン酸含量に增加の傾 向がみられ, 一方, $1{ }^{\circ} \mathrm{C}$ 貯蔵では有孔, 密封両区とも徐 タに減少した。還元型アスコルビン酸と酸化型アスコル ビン酸の比率は, 収穫直後では $3: 7$ であったが, 還元 型アスコルビン酸のほとんどは貯蔵中に酸化型アスコル ビン酸に変化した。

謝 辞本実験の実施並びに本稿を取りまとめるに あたり, 多大な助言を賜った大阪府立大学 岩田 隆教 授に深く感謝の意を表します。

\section{文献}

1） ゴーラムモーラ・伊藤三郎：日食工誌，30，8，454 (1983)

2）菅原友太 : 農, 園芸作物のビタミンCに関する研究（養賢 堂) (1957)

3 ）泉 秀美・辰巳保夫・邨田卓夫：日 食工誌，31，1，47 (1984)

4) 山内直樹 - 山脇和樹 - 上田悦範 - 茶珍和雄 : 園学雑, 53, 3,347 (1984)

5) 山内直樹 - 浜口辰治・緒方邦安 : 園学雑, 49, 3, 414 (1980)

6）近 雅代・榛葉良之助：日食工誌，35，6，423 (1988)

7）梅田圭司・川嶋浩二：日食工誌，18，4，147 (1971)

8) Gross J.: Chromatogr., 13, 9, 572 (1980)

9）大礒敏雄・鈴江緑衣郎・印南 敏・小林修平・山口賢次・ 橋本 勲・板倉弘重 : 健康 - 体力づくりの栄養学 (大修館書 店) p. 147 (1988)

10) Simpson K.L.: Proc. Nutr. Soc., 42, 7 (1983)

11）大阪府立大学農学部園芸学教室編 : 園芸学実験・実習（盖 賢堂) p.183 (1983)

12) Davies, B.H. : Chemistry and Biochemistry of Plant Pigments, 2nd ed. vol. 2, Ed. Goodwin, T.W. (Academic Press, New York), p.38 (1976)

13) Yokoyama, H. and White, M. J. : J. Agric. Food Chem., 15, 693 (1967)

14）林 孝三編：増訂 植物色素 実験研究への手引き（養賢 堂) p.38 (1988)

(平成 2 年 7 月 30 日受理) 